\title{
'GREATNESS' AND AUSTRALIAN LITERATURE IN THE 1930S AND 1940S: NOVELS BY DARK AND BARNARD ELDERSHAW
}

\section{By PATRICK BUCKRIDGE}

LITERARY studies has for some time now been rediscovering the value and interest of an analytical style of literary history, one that tries --not without some inferential synthesis and speculation -- to place literary texts and events in richer, more finely differentiated relations to their immediate cultural milieux than were envisaged by earlier critical tendencies, whether (in the Australian instance) formalist exclusions or nationalist over-generalisations of historical context. There is now, it would seem, an assured place on the academic agenda for historical arguments which, while not seeking to write the spiritual history of the nation in its literature, are more than merely descriptive of documented facts and relations concerning the processes of transmission, interaction and transformation of texts. Internationally, I am thinking especially of the sparkling essays of Robert Darnton on French book culture, and of work by Cathy Davidson and others on North American (Darnton, The Great Cat Massacre, The Kiss of Lamourette; Davidson, Reading in America). On the Australian scene, elements of this approach are present.[1]

This paper is a contribution to analytical literary history in that sense. In it I analyse a single aspect of Australian literary culture in a particular historical period, namely its interest in 'greatness' --great books and great authors, especially the latter -- in the years between the Depression and the end of the Second World War. But I try to do so in a way that makes some connections with a broader and longer process of discursive transformation over time, thereby illuminating (both by analogy, and even, perhaps, by weak causalities of certain kinds) similar interests in different periods, notably our own.

No discussion of 'greatness' in literature can hope to get far without connecting itself to that much-canvassed topic, 'the canon'. My sense of the terminology is that 'greatness' and 'canonicity' are not interchangeable concepts, though they are sometimes taken to be so. Canons, after all, may function in very different ways -for example, as pedagogical vehicles or as cultural Baedekers -- and this fact clearly complicates the membership criteria. The 'greatness' of a work, one might suppose, would always be a sufficient condition to assure its membership of most canons; but it may not be a necessary one. In any case, for my limited purposes I propose the following as a working definition of the kind of canonicity I shall be interested in here: 'A national literary canon is a relatively short list of books or authors, ranging across several generations, which are taken to be the best and most characteristic products of the nation's literature.'

I assume the viability of this definition in offering the following historical proposition: that Australian literary culture in the 1930s and 1940s was in a state of 'canonical anxiety'. What I mean by this is that in this period the institution of Australian Literature -- its writers, critics, publishers and general readers $m$ seems to have been preoccupied with, and deeply uncertain about, questions like whether Australia had a national literary canon; if it did, what writers and works belonged to it, and how these should be used; if it didn't have one, what should be done to foster its development?

This was by no means the first time that questions of this kind had arisen in Australia, nor would it be the last: such anxieties began to be expressed in the latter half of the nineteenth century, and they continue into the present.[2] Perhaps they are among the characteristic questions of a colonial culture in the process of becoming post-colonial. But if such canonical anxiety is not unique to the ' 30 s and '40s I believe it developed a particular edge in these decades, and that those questions about the national literature were being asked and answered in new and distinctive ways.

A number of large 'world-historical' factors -- most notably the Great Depression, changes in Soviet cultural policy, and the outbreak of the Second World War -- had a bearing on the 
Australian situation in this period. Both the radical-reformist interest in literature as an instrument for analysing the breakdown of the economic and social system, and the conservative interest in it as a repository of traditional social values, combined to strengthen a perceived obligation to articulate 'Australian literature' as an ideologically coherent (if also dynamic and developing) body of writing (Reid, Literature and the Great Depression; Carter, 'Documenting and Criticising Society'). At the same time, Australia's global political environment, particularly its wartime strategic relations with Europe and the United States, was taking on a new importance, the consequences of which certainly included a new sense of the visibility of Australian literature in the wider world, and of the inevitability of crossnational literary comparisons. A classic instance of the new perspective might be the series of 'canon-exchanges' initiated late in 1942 by the East and West Association, an American body headed by Pearl Buck, which arranged for a number of Allied countries to exchange lists of their best and most characteristic books. (The Sydney Daily Telegraph,7 December 1942 responded enthusiastically on Australia's behalf).

There was also an internal structural factor of great importance in creating a climate conducive to national canonical anxiety. This was that Australia in this period (for better or worse) had no academic apparatus of canon-formation and maintenance, of the kind that had developed in other Anglophone cultures in association with the task of teaching the national literature in universities, something that did not begin to happen in Australian universities, by and large, until the 1950s. Comparisons with Britain and the United States, where the universities' involvement in constituting a national canon was well-established by this time, highlight the Australian difference.

It has sometimes been implied that literary journals performed a canonising role for Australian literature comparable to that performed elsewhere by university teaching (Docker; Milner). But it is most unlikely that fledgling journals like Southerly and Meanjin (founded in 1939 and 1940 respectively) could have conferred anything like the institutional legitimacy and canonical stability of the universities. The authority of the older Communist Review extended to a fairly narrow left constituency at most (Carter, 'Reviewing Communism'); while at the other end of the political spectrum, the Bulletin, once an instrument of considerable cultural authority, had lost much of this authority by the late 1930s through a general cultural and political conservatism, and more specifically because it was 'soft on Fascism' in Europe at a time when the weight of intellectual opinion in Australia was moving in the opposite direction.

Similar, or at least complementary, observations could be made about the state of Australian publishing in this period. Angus and Robertson published remarkably little Australian literature; its role as a recognised 'national publisher' was still a thing of the future. And companies like the Endeavour Press and P.R. Stephensen and Co., though vigorous enough in the first flush of their literary nationalism, were too shortlived to confer canonical status on the books they published (Munro 115-49). Australia in the 1930s and early 1940s seems, in short, to have lacked the sort of cultural authority structure needed to constitute, stabilise and disseminate a literary canon, and hence to sustain a secure, public sense of itself as a country with a respectable national literature. The theme of Australia's cultural 'mediocrity' and lack of tradition is a commonplace among writers and intellectuals of the interwar years (Walker, Dream and Disillusion 148-67).

The argument I want to develop here is that one of the 'anxious' responses to a perceived absence of cultural authority was a preoccupation with the idea of 'greatness' in Australian literature. Functioning sometimes as a mythic panacea, sometimes as an exhortation, sometimes as a reproach, greatness figured variously as what Australian literature needed, what it already had, what it could never hope to have, or what it was almost certainly just about to achieve. There was also room for a range of views as to how it should be understood and applied: whether to individual writers, to whole literatures, to races, or to languages. All the options and possibilities jostled for a hearing in these decades, and one would not wish to privilege one strand in the fabric unduly. Yet for all that, there does seem to be a certain directionality in the discourse: it has to do, I think, with the ways in which the relationship between greatness and women was changing in this period. This is a theme to which I shall return. 
The idea of greatness itself, meanwhile, has a variety of intellectual sources. As applied to literature and the other arts, it has strong connections with the aesthetics of sublimity, with its central notion of the power that disarms criticism and defies categorisation. Greatness also figures prominently in Romantic constructions of the artist-as-visionary; and in Romantic and post-Romantic historiography and political theory it appears as the great historical individual -almost invariably the great man -- in the work of Nietzsche, Max Weber and Freud (Bologh).

All of these traditions have some relevance to the ways in which literary greatness functions as an idea in the time and place under consideration; but it is, after all, such a robustly nontechnical term that it goes without saying that it is mostly used -- even within literary discussion -- without any indication of particular intellectual provenances. I am more interested here, in any case, in what was done with the idea than in where it came from.

One of the reasons why 'greatness' was a useful conceptual instrument for dealing with a state of canonical anxiety was that it allowed the problem of the canon to be addressed on two fronts: as a question about Australia's literary past, its 'heritage', and as a question about Australia's literary present and future. Some commentators, it is true, made limited gestures of canonical faith. Rex Ingamells, for example, singled out four novels -- For the Term of His Natural Life, The Fortunes of Richard Mahony, Landtakers, and A House Is Built -- as 'the best four Australian novels to date' (Barnes 261); Miles Franklin and others, including the American critic $\mathrm{C}$. Hartley Grattan, campaigned for years to gain a wider recognition of the greatness of Such Is Life. [4] 'But all of these would also have agreed with Vance Palmer and Louis Esson that Australian literature was, for the moment at least, a literature that had not achieved true greatness (Walker, Dream and Disillusion 8-9, 12).

Nettie Palmer even provided a rationale for this state of affairs with her distinction between 'absolute value' and 'relative value'. The former is a quality of all 'great literature' (her examples are Milton, Bunyan and Conrad), the latter an index of 'the sheer usefulness of a literary work in interpreting a given environment to the people in it and to its observers' (Smith, Nettie Palmer 358-59). Australian literature need not necessarily aspire to the heights of 'absolute value', and the search for the Great Australian Novel -- 'that most futile phrase' -can be discontinued in favour of 'a great variety and number of books . . . each . . . to be accepted for its own contribution to Australian letters' (382). Others were not quite so comfortably resigned to a literature without absolutes -- Nettie herself may not always have been so -- and if an Australian canon of absolute value could not be convincingly derived from the past, then the focus could shift to the possibility of discovering and identifying greatness in the present (greatness being understood, perhaps, as sufficient for canonicity, and therefore, in effect, a guarantee of canonical status).

To put it another way, greatness seems to have functioned as a projection into the present of the utopian possibility of whatever mysterious quality it was -- call it 'timelessness' -- that made certain authors and works of the past survive as 'classics'. The greatness of certain authors or works in the established English, European, even the American, canons could be taken for granted;[5] their greatness was synonymous, in effect, with their canonicity. In the uncanonised field of Australian literature, though, attributing greatness to an author was riskier (since, by implication, it looked to posterity to ratify the attribution); it was also a more 'pro-active', even utopian gesture, since it was in itself a way of sowing the seeds of a future canon.

Some of these concerns appeared, in a practical form, in a Red Page article by Cecil Mann towards the end of 1930 in which he attacked Vance Palmer's view that what Australian literature needed above all was a critic of the stature of H.L. Mencken. Mencken, Palmer claimed, had almost single-handedly created the American literary canon by discovering and disseminating what was dynamic in both past and present American writing. Mann's sarcastic response was that such a paragon would find it hard to keep himself occupied, let alone edified, with the quantity of 'dynamic' Australian writing he would be able to lay his hands on, and that Australian literature would be better served if critics simply kept out of the way of the great creative artists who were yet to appear. Nettie Palmer's private rejoinder on Vance's behalf, was that they (the Palmers) had 'no illusions' as to the greatness of 'our national achievements' in literature, and that the task of discrimination between 'what is significant and 
germinating' and 'mere commercial ephemera' remained an important critical prerogative (Smith, Letters 61).

The exchange is useful in pointing up the common objective (the creation of a national canon) and the different roles envisaged for criticism in working towards it. Indeed it is possible, on this basis, to begin to distinguish two rather different groupings operating in Sydney throughout the 1930s: the Bulletin group, a Norman Lindsay-dominated circle which included P.R. Stephensen, Brian Penton, Godfrey Blunden, Ronald McCuaig and others; and the Fellowship of Australian Writers group, which included people like Marjorie Barnard, Flora Eldershaw, Frank Davison, and Katharine Susannah Prichard. The groupings were not mutually exclusive as to persons, nor were they more than occasionally antagonistic. But they did display significant differences on questions like the role of literary critics: were they important helpers to creative writers -- almost midwives to the national literature (a Fellowship view); or were they, at best, the scourges of bad writing (a Bulletin view)?

Other, related differences emerge in relation to conceptions of realism, reasons for opposing censorship, and approved strategies for national literary development. For the Fellowship group, for example, creative writing classes were a highly favoured strategy, whereas these were held in something bordering on contempt by the Bulletin group. For the latter group, literary competitions seemed the better way to go; and these, in turn, were regarded with some suspicion by the Fellowship.

Such differences of cultural diagnosis and strategy are often difficult to elaborate with reference to the groups themselves. As much as anything this is a problem of evidence. Much of the thinking and discussion that went on around these questions was unrecorded and is now scarcely retrievable even by interview. We can, however, look to some of the novels by people within that milieu as a way of pursuing some of the cultural-political ramifications of different responses to the same perceived problem. (This is a matter of treating novels not as direct reflections of 'real life', but as particular vehicles for the very 'real' intellectual and imaginative work that was going on at that time and place.)

Two novels, both published in 1937, elaborate the discourse of greatness in a variety of interesting ways. Eleanor Dark's Sun Across the Sky and M. Barnard Eldershaw's Plaque With Laurel both deal, in very different ways, with the phenomenon of the unquestionably great author. Generically, the novels are poles apart: the first a somewhat melodramatic psychological drama, the second a heavily populated and rather' diffuse social comedy. Central to each work, however, is a Great Author who plays very little part in the action, to whose consciousness the reader is given no access, but who functions nonetheless as a key reference point for most of the major themes.

Patrick Nicholas Kavanagh, in Sun Across the Sky, is a great poet of Irish extraction and immense classical learning who bears a striking resemblance to Christopher Brennan, a connection which is not explicitly acknowledged, though there is a three-stanza epigraph from Brennan. (The character's relationship, if any, to the contemporaneous Irish poet Patrick Kavanagh is unclear.) The novel is set in a small coastal resort which is in the process of being 'developed' by a philistine capitalist, Sir Frederick Gormley, against the implacable opposition of Kavanagh, who owns some of the town's poorer houses and refuses to sell to Gormley. Gormley eventually loses patience and hires someone to start a fire which destroys Kavanagh's section of the town and, indirectly, kills Kavanagh in the process.

The main protagonist, however, is a doctor, Oliver Denning, whose wife Helen is constructed as a psychiatric case study in sexual 'frigidity'. Oliver, who overflows with vitality, sexual and otherwise, has just begun a relationship with Lois, a painter of increasingly recognised genius. Oliver and Lois have both drunk deep at the spring of Kavanagh's greatness; indeed, their relationship was first consummated after an evening with Kavanagh, listening to his poetry and Beethoven's music; and the climax of the novel comes when Oliver rescues Kavanagh's manuscripts from his burning house, injuring himself in the process, but managing to place them in the hands of Myra, Gormley's young mistress.

All but the most minor characters are constructed and implicitly judged with reference to Kavanagh, who stands as an ideal embodiment, not just of artistic achievement, but of 
uncompromising resistance to economic vandalism, the dominance of the profit motive, and every form of social and psychological imprisonment of the human spirit. Lois's late husband Kit, a prolific but shallow and formulaic writer, seems to be there (in flashback) as a foil for the profundity and originality of Kavanagh; Lois herself, by contrast, is presented as having more than a touch of Kavanagh's greatness in her own medium of paint. Her corresponding foil is Oliver's repressed wife Helen, who does technically perfect but lifeless embroidery.

Like the Bulletin group, with whom she had some limited contact, Dark sees the function of great art as that of a continuously inspiring demonstration of the human capacity for selfexpression rather than as a direct source of ethical or political truth. When Oliver Denning gazes at Kavanagh's manuscript he sees words 'assembled by genius into an order which made them immortal'. Together they constitute a voice 'which a man had fashioned out of the past of mankind for the future of mankind', a voice 'struggling to its expression through words or through music or through form, so that for every snarl of the beast which rose in him there came returning always the answering paean of his godhead' (Dark 163).

But can Australia give birth to a 'great tradition' of this sort of thing? When Oliver looks at the sunbathers on the beach, he wonders 'whether the background of warmth and colour which was being burned into them by some mysterious chemistry of rays outside the spectrum, were building up in them too, slowly and imperceptibly, that ebb and flow of intense emotion, that fierce love of life for the sake of living which is the true environment of all great art' (36).

As it happens, this passage is immediately followed by a near-fatal shark attack, but the utopian structure of the narrative as a whole expresses optimism: Kavanagh may be unappreciated in his own time, but Lois Marshall's work is already being celebrated -- and indeed, in her view, over-interpreted! There is an interesting sequence here in which the art public's complex allegorical 'over-readings' are first ridiculed, then tolerated, then defended by Oliver as a legitimate and even valuable way of appropriating great art, not to be discouraged by the artist's equally legitimate and conventional incomprehension of those same readings. The dramatic rescue of Kavanagh's manuscripts, however, is the clearest gesture of utopian faith, signifying as it does both a proper reverence for artistic greatness itself, and a determination to perpetuate its effects beyond the single extraordinary life.

One thing that emerges fairly clearly from Dark's novel is the patriarchal nature of the discourse of greatness. Feminist theory has demonstrated the masculinism of the ideal of heroic greatness constructed in the work of Sigmund Freud and Max Weber, and Dark's formulations of Kavanagh's greatness make it clear that the masculinism is entirely transferable from the political to the cultural domain: she uses the same gender-coded paradigm of qualities -- power, independence, individuality, vitality, self-denial -- as Weber used in his typifications of the Great Man of modern history; and as Norman Lindsay used in his numerous accounts, in Creative Effort and elsewhere, of the nature of the Great Artist. The gender of Lois Marshall obviously mitigates this bias a little -- her genius is said to be of a purely 'intuitive' (i.e. feminine) kind -- but it could hardly be said that the novel as a whole seriously challenges the masculinism of the discourse. Rather, it reproduces it -- with some qualification -as the imperfect instrument needed to articulate the desire for a true national canon.

Plaque with Laurel refuses that particular compromise, which is part of what makes it such an interesting companion piece to Sun across the Sky. It is, if anything, even more singlemindedly focussed on the specific problem of the cultural appropriation of greatness, the problem, that is, of how (and perhaps if) a nation without a literary canon can use the greatness of its individual writers to create one. The great writer in this case is Richard Crale. Crale (unlike Kavanagh) is already dead, and the novel is the story of a three-day writers' conference in Canberra, organised by the so-called 'Guild of Australian Writers' to commemorate his life's work and to erect a plaque in his honour (hence the title).

The dominant tone is satiric and pessimistic. Satiric about most of the delegates' ignorance of, and lack of interest in, Crale's work; and also, in a more serious vein, about the different and incommensurable perceptions of Crale himself by the three people closest to him in life: his widow, his lover, and his old friend Jim Walters, the conference organiser. In view of the virtual dismemberment and dispersal of Crale's greatness, the novel is pessimistic about the 
prospect of successfully grafting the dead author's genius onto the modest stock of Australian writing.

This novel organises its system of foils rather differently from the other. Here the effect is not so much to define the quality of greatness, which is almost taken as read, but to illustrate different modes of national appropriation of literary greatness. There is, for example, a representative of the old, authoritative, but irrelevant English canon: Professor Standish, Acting Professor of English at the University of Sydney, who has read no Australian literature, but is given several pages in which to make a speech about the quality of greatness in art, and to inveigh against democracy and 'the journalistic cast of mind' to an audience mainly composed of journalists. There is Ida Crale, the widow, who is 'not literary', and for whom Crale's greatness meant nothing more than a steady income. There is Owen Sale, a writer seemingly in the middle of a nervous breakdown, who is obsessed with guilt at having snubbed Crale for alleged cowardice in the last war, and who tries to expiate it with his suicide on the third day.

Most importantly, there are Jim Walters and Crale's lover Imogen Tarrant: Walters' reverence for Crale's work and his strong commitment to perpetuating his reputation augur well, it would seem, for a successful grafting operation. But in a remarkable turn, Imogen is able to argue very persuasively that for all his loyalty Walters is as imprisoned as Owen Sale was within an essentially masculine conception of Richard Crale's careen In opposition to Walters' implicit demand for a hierarchical institution of literature, owned and commanded by the Great Authors at the apex, who are revered and emulated by the struggling hacks below, she argues for a sharing literary community of complementary strengths and weaknesses.

Don't you think that perhaps we do make a whole between us, even if each one only contributes a little? it doesn't mean that there is no pattern because we can't see it. We might make up for one another in the end somebody's plus fits into somebody else's minus. Like a jigsaw, you know. There's a whole, but it doesn't belong to anyone. We share it. (Eldershaw 295)

In the end, then, I think the novel ends up rejecting the Great Man theory of canon-creation in favour of a distinctly feminine, if not feminist, re-visioning of the literary institution as a whole, along 'communitarian' lines. In their critical essays of the same period, Barnard and Eldershaw evince a somewhat stronger feminism and a more canonical conception of the national literature than in their novel: 'to allot places in a hierarchy is dangerous', they declare; but they find it hard to resist it themselves, and Richardson and Prichard are hailed as 'foundation stones of a new era' in Australian literature (3).

The balance shifted decisively in a very few years. In an essay Marjorie Barnard wrote five years later for the collection Australian Writers Speak, she espoused a radically anti-canonical conception of the development of a national literature: organically and anonymously, from the ground up, rather than authoritatively or charismatically, from the top down (Davison 97-105). The almost mystical organicism of that essay is thus foreshadowed in Plaque with Laurel, but the 1942 essay, a product of the war years, lacks the explicitly feminine dimension present in the novel.

The radically alternative solution to the 'canon problem' hinted at in Plaque with Laurel remained marginal to debates about the national literature for decades. But the gender critique of literary greatness on which the solution rested may well have had some impact, even at the time. That, at least, is what my last group of examples would seem to suggest.

Brian Penton, as it happens, also wrote a novel in 1937, a first draft of his still-unpublished third novel of the Landtakers trilogy. It too is a novel about greatness and the canon. It establishes not just one, but two canonical successions within the one family. In one of them, a young writer derives his inspiration and motivation directly through his association with an ageing and alcoholic poet, who is also a Professor of Classics. In the other, somewhat more idealised succession, the young writer's slightly older brother, a very talented composer, derives his inspiration from Debussy and Henry Lawson -- an interesting mix! His magnum opus, performed to great acclaim in the Sydney Town Hall in the 1920s, is a symphonic rendering of Lawson's sketch 'In a Dry Season'.[6] 
If Penton did see an Australian canon emerging in the 1930s, we can infer from his reviews and other critical writings that it would have contained some surprising names: W.J. Turner, for example, he considered to be 'Australia's greatest living poet'; and for fiction Godfrey Blunden and Leslie Meller looked the most promising of the younger generation. Lawson was there too, but his greatness chiefly consisted, for Penton, in the eloquence and conviction with which he sometimes expressed his hatred for Australia.

What is not surprising is the masculinity of Penton's canon. Less than ten years later, however, even a Lindsayan chauvinist like Penton could sense a change in the literary topography. In a long obituary for Henry Handel Richardson in 1946, significantly titled 'Henry Handel Richardson: Great and Lonely', he seems to have discovered the possibility of a great female progenitor of Australian literature. Presumably that possibility had become thinkable, in part, because a woman-centred canon had already begun to be imagined by novelists like Eleanor Dark, M. Barnard Eldershaw and others ten years earlier. It is true, in any case, that under Penton's editorship the Daily Telegraph in the early and mid-'40s published a number of ground-breaking articles on Christina Stead, Katharine Susannah Prichard, Eleanor Dark and Kylie Tennant.

By the early 1950s, the idea of a modern Australian canon dominated by women was not just thinkable; it was old news. Women writers had won the two big nationwide novel competitions of the late '40s, and articles were being published in Meanjin and Southerly in which the merits of Dark and Prichard were debated with the kind of close attention seldom given to non-canonical texts. In 1950, Nettie Palmer published her monograph on Henry Handel Richardson, placing her confidently as a 'world writer', comparable with writers like Ibsen, Strindberg and Kierkegaard (Palmer 185). And by the mid-Fifties, Miles Franklin was making extended comparisons between Catherine Helen Spence's Clara Morison and works by Jane Austen and Flaubert (Franklin 52-68). Women were beginning to consolidate their place, not just in the Australian, but in the international literary canon.

From the 1950s on, though, the whole question of the canon became increasingly the 'business' of the academy, as Australian literature, belatedly, began to be taught in the universities. Of the many conditions that determined Patrick White's emergence as Australia's 'great writer' par excellence for the next two decades at least, this was certainly an important one.

1. In, for example, the work of lan Reid, G.A. Wilkes, Graeme Turner, and John Docker; in several essays in the Penguin New Literary History of Australia, and in some recent collections on the book in Australia.

2. See for example, Desmond Byrne, Introduction to Australian Writers (1896), in Barnes 5061. For an account of more recent canonical debates in Australia, see my 'Canons, culture and consensus: Australian literature and the Bicentennial' in Bennett et al. 69-86.

3. For a representative contemporary comment on the decline of the Bulletin, see Brian Penton, Daily Telegraph (Sydney) 6 March 1943.

4. Letter from Miles Franklin to Eleanor Dark, 6 September 1943, in Ferrier 104-05; Grattan 67-76.

5. The American canon is usually taken to have stabilised as late as the $1920 \mathrm{~s}$, with the growth of what Paul Lauter (435-63) calls 'the academic institutionalisation of reading choices'. However, it is interesting that the Australian critic Desmond

Byrne, writing as early as 1896, regarded as axiomatic the greatness of Franklin, Irving, Hawthorne and Emerson (Barnes 50).

6. MS in Brian Penton Papers, UQFL 230, Fryer Library, University of Queensland. 
WORKS CITED

Barnes, John, ed. The Writer in Australia, 1856-1964. Melbourne: Oxford UP, 1969.

Bennett, Tony, Pat Buckridge, David Carter, and Colin Mercer, eds. Celebrating the Nation: A Critical Study of Australia's Bicentenary. Sydney: Allen \& Unwin, 1992.

Bologh, Roslyn Wallach. Love or Greatness: Max Weber and Masculine Thinking: A Feminist Inquiry. London: Unwin Hyman, 1990.

Carter, David. 'Reviewing Communism: "Communist Review" (Sydney) 1934-1966: A

Checklist of Literary Material.' Australian Literary Studies 12.1 (1985): 93-105.

----. 'Documenting and Criticising Society.' Hergenhan, gen. ed. 370-89.

Daily Telegraph. Sydney: Consolidated Press.

Dark, Eleanor. Sun across the Sky. London: Fontana, 1962.

Darnton, Robert. The Great Cat Massacre and Other Episodes in French Cultural History. Harmondsworth: Penguin, 1984.

----. The Kiss of Lamourette. London: Faber \& Faber, 1990.

Davidson, Cathy, ed. Reading in America: Literature and Social History. Baltimore and London: Johns Hopkins UP, 1989.

Davison, Frank Dalby, ed. Australian Writers Speak. Sydney: Fellowship of Australian Writers, 1942.

Docker, John. Australian Cultural Elites. Sydney: Angus \& Robertson, 1974.

-----. In a Critical Condition. Ringwood: Penguin, 1984.

----. The Nervous Nineties: Australian Cultural Life in the 1890s. Melbourne: Oxford UP, 1991.

Eldershaw, M. Barnard. Essays in Australian Fiction. Melbourne: Melbourne UP, 1938.

Ferrier, Carole, ed. As Good as a Yarn with You. Oakleigh, Vic.: Cambridge UP, 1992.

Franklin, Miles. Laughter, Not for a Cage. Sydney: Angus \& Robertson, 1956.

Grattan, C. Hartley. 'Tom Collins's "Such Is Life".' Australian Quarterly 9.3 (1937): 67-76.

Ingamells, Rex. 'Conditional Culture' (1938). Barnes 261.

Lauter, Paul. 'Race and Gender in the Shaping of the American Literary Canon: A Case Study from the Twenties.' Feminist Studies 9 (1983): 435-63.

Milner, Andrew. 'The English Ideology: Literary Criticism in England and Australia.' Thesis Eleven 12 (1985): 110-29.

Munro, Craig. Wild Man of Letters: The Story of P. R. Stephensen. Melbourne: Melbourne UP, 1984 .

Palmer, Nettie. Henry Handel Richardson: A Study. Sydney and London: Angus \& Robertson, 1950. 
Reid, Ian. Literature and the Great Depression: Australia and New Zealand, 1930-1950. Melbourne: Edward Arnold, 1979.

Smith, Vivian, ed. Letters of Vance and Nettie Palmer. Canberra: National Library of Australia, 1977.

-----. ed. Nettie Palmer. St Lucia: U of Queensland P, 1988.

Walker, David. Dream and Disillusion: A Search for Australian Cultural Identity. Canberra: ANU Press, 1976. 